\title{
EULAR recommendations for the use of imaging in the clinical management of peripheral joint osteoarthritis
}

\author{
Garifallia Sakellariou, ${ }^{1}$ Philip G Conaghan, ${ }^{2}$ Weiya Zhang, ${ }^{3}$ Johannes W J Biilsma, ${ }_{1}^{4}$ \\ Pernille Boyesen, ${ }^{5}$ Maria Antonietta D'Agostino, ${ }^{6,7}$ Michael Doherty, ${ }^{3}$ Daniela Fodor, ${ }^{8}$ \\ Margreet Kloppenburg ${ }^{9}{ }^{\text {Falk Miese, }}{ }^{10}$ Esperanza Naredo, ${ }^{11}$ Mark Porcheret, ${ }^{12}$ \\ Annamaria lagnocco ${ }^{13}$
}

\begin{abstract}
- Additional material is published online only. To view please visit the journal online (http://dx.doi.org/10.1136/ annrheumdis-2016-210815)

For numbered affiliations see end of article.
\end{abstract}

\section{Correspondence to} Professor Philip G Conaghan, Leeds Institute of Rheumatic and Musculoskeletal Medicine, Chapel Allerton Hospital, Leeds LS7 4SA, UK; p.conaghan@leeds.ac.uk

GS and PGC contributed equally.

Received 12 November 2016 Revised 25 February 2017 Accepted 5 March 2017 Published Online First 7 April 2017

\section{CrossMark}

To cite: Sakellariou G, Conaghan PG, Zhang W, et al. Ann Rheum Dis 2017;76:1484-1494.

\section{ABSTRACT}

The increased information provided by modern imaging has led to its more extensive use. Our aim was to develop evidence-based recommendations for the use of imaging in the clinical management of the most common arthropathy, osteoarthritis (OA). A task force (including rheumatologists, radiologists, methodologists, primary care doctors and patients) from nine countries defined 10 questions on the role of imaging in $O A$ to support a systematic literature review (SLR). Joints of interest were the knee, hip, hand and foot; imaging modalities included conventional radiography (CR), MRI, ultrasonography, CT and nuclear medicine. PubMed and EMBASE were searched. The evidence was presented to the task force who subsequently developed the recommendations. The strength of agreement for each recommendation was assessed. 17011 references were identified from which 390 studies were included in the SLR. Seven recommendations were produced, covering the lack of need for diagnostic imaging in patients with typical symptoms; the role of imaging in differential diagnosis; the lack of benefit in monitoring when no therapeutic modification is related, though consideration is required when unexpected clinical deterioration occurs CR as the first-choice imaging modality; consideration of how to correctly acquire images and the role of imaging in guiding local injections. Recommendations for future research were also developed based on gaps in evidence, such as the use of imaging in identifying therapeutic targets, and demonstrating the added value of imaging. These evidence-based recommendations and related research agenda provide the basis for sensible use of imaging in routine clinical assessment of people with $\mathrm{OA}$.

\section{INTRODUCTION}

Osteoarthritis (OA) is a major cause of pain and disability worldwide. Although conventional radiography (CR) is the most commonly used technique to evaluate structural features of $\mathrm{OA}$, significant advances have been made in the field of imaging over the last decade, allowing a more accurate evaluation of both bone and soft-tissue abnormalities. While newer modalities such as MRI and ultrasound have increased the understanding of the multiple pathologies contributing to the OA phenotype, it is not clear how they should be used in routine care. The role of imaging in clinical practice for OA diagnosis, management and follow-up has not been clearly defined. Despite this limitation, the increased availability of modern imaging has expanded its use, with possible excesses ${ }^{1}$ leading to increased costs. A European League Against Rheumatism (EULAR) task force was therefore created to develop evidence-based recommendations on the use of imaging in the management of symptomatic, peripheral joint OA, for clinicians who treat $\mathrm{OA}$ in their clinical practice.

\section{METHODS}

A group selected from a range of expertise (rheumatologists, radiologists, primary care physicians, methodologists and patients) and representing nine countries was included in the task force. During the first meeting, the focus of the recommendations (symptomatic OA affecting the knee, hip, hand or foot) was clarified. Clinically relevant questions on the application of imaging in OA were proposed and nine research questions were selected by consensus to guide a detailed systematic literature review (SLR). Two questions that covered the same area were subsequently combined. The areas of diagnosis, prognosis, follow-up and treatment were covered. The questions were rephrased according to the population, intervention, comparison, outcome (PICO) (see online supplementary file S1 research questions).

An SLR was performed by one of the authors (GS), with checking of all extractions by one of three other authors experienced in SLRs. The search strategies were based on both MeSh terms and free text. The searches were performed separately for each joint (see online supplementary file S2 search strategies). The titles and abstracts of the references that were retrieved were screened by the same author according to predefined inclusion and exclusion criteria, based on the PICO for each question, and potentially relevant articles were evaluated in their full text. Studies in English including adults $(\geq 18)$ with symptomatic OA of the knee, hip, hand and foot were eligible for inclusion. Imaging modalities included were CR, MRI, ultrasonography (US), CT and nuclear medicine techniques (scintigraphy, positron emission tomography). Randomised controlled trials (RCTs), systematic reviews and meta-analyses, controlled clinical trials, case-control studies, cross-sectional studies and cohort studies were eligible for inclusion. Studies had to examine the role of imaging in 
the following: in making a diagnosis of $\mathrm{OA}$; in detecting $\mathrm{OA}$ elementary lesions; for differential diagnosis; in the management of $\mathrm{OA}$; in predicting outcome and therapeutic response; for follow-up of disease course and to guide treatment. The same articles could be included in more than one search. Due to the variety of joint sites and imaging and the expectation of a strong degree of heterogeneity across studies, meta-analyses were not prespecified before study selection and extraction. The methodological quality of the included studies was not assessed by quality scores, but some aspects were considered for all studies, together with design-specific indicators. For all studies, study design, sample size and setting sampling were considered. For RCTs allocation concealment, drop-out rate as well as the presence of funding, for diagnostic studies the adequacy of the reference standard and for cohort studies the presence of adjustment for confounders were also evaluated. Each aspect was evaluated separately as leading to high, low or unclear risk of bias.

During the second meeting, the results of the literature review were presented and the experts developed 'over-arching' statements (background statements to preface the recommendations) and drafted seven recommendations through a process of discussion and consensus. The number of recommendations emerged through the discussion after the presentation of the literature. To explore the presence of additional evidence concerning two recommendations, two more research questions on (1) the different performance of various radiographic views in detecting OA features and (2) the accuracy of imaging-guided compared with blind joint injections were added to the original eight, with two additional literature searches (see online supplementary file S1, research questions and S2, search strategies). After evaluation of these results, the Task Force confirmed the final wording of the recommendations and scored the perceived level of agreement (LOA) for each statement using a 0-10 numeric rating scale $(0=$ fully disagree; $10=$ fully agree), reflecting both literature evidence and expert opinion. Recommendations for further research were then developed based on gaps in the SLRs.

\section{RESULTS}

The searches in the electronic databases (PubMed, EMBASE) were performed up to the end of January 2015 for the main searches and December 2015 for the additional searches. The initial search resulted in 6858 records (615 duplicates). Of the remaining 6243 articles, 4926 were excluded based on the title and abstracts, leaving 1317 articles for detailed review. All fulltext articles were retrieved, 986 articles were excluded after reviewing the full text, leaving 331 articles for inclusion (see online supplementary file S3). The hand search of the references of the included studies identified 33 additional articles, leading to a total of 364 studies finally analysed. Articles that were relevant to more than one research question were used for each question as appropriate. The number of articles included for each site and imaging is shown in online supplementary figure S4. The complete results of the SLR with references are reported in the online supplementary file S5.

The additional search on the comparison of different radiographic views resulted in 4774 articles (225 duplicates). Of the remaining 4549, 4496 were excluded based on the title and abstracts, leaving 53 articles for detailed review. Twenty-three articles were excluded after reviewing the full text, leaving 30 articles for inclusion. The hand search identified one additional article for inclusion, leading to a total of 31 articles finally included (see online supplementary file S6).

The additional search on the added value of imaging to guide intra-articular procedures resulted in 5379 articles
(834 duplicates). Of the remaining 4545,4520 were excluded based on the title and abstracts, leaving 25 articles for detailed review. Nineteen articles were excluded after reviewing the full text, leaving six articles for inclusion. The hand search identified two additional articles for inclusion, leading to a total of eight articles finally included (see online supplementary file S7). The complete results of the additional searches with references are reported in the online supplementary file S8.

\section{Recommendations}

Table 1 summarises the seven recommendations with their corresponding level of evidence and LOA. Each recommendation is presented in detail below.

\section{Overarching statements}

1. These recommendations pertain only to symptomatic OA.

2. Imaging abnormalities of $\mathrm{OA}$ are commonly seen especially with increasing age.

Table 1 Recommendations, levels of evidence and level of agreement (LOA)

\begin{tabular}{lll}
\hline Recommendation & $\begin{array}{l}\text { Level of } \\
\text { evidence }\end{array}$ & $\begin{array}{l}\text { LOA, mean } \\
(95 \% \mathbf{C l})\end{array}$ \\
$\begin{array}{l}\text { 1. Imaging is not required to make the } \\
\text { diagnosis in patients with typical* } \\
\text { presentation of OA. }\end{array}$ & III-IV & $8.7(7.9$ to 9.4) \\
$\begin{array}{l}\text { 2. In atypical presentations, imaging is } \\
\text { In }\end{array}$ & IV & $9.6(9.1$ to 10)
\end{tabular}
recommended to help confirm the diagnosis of $\mathrm{OA}$ and/or make alternative or additional diagnoses.

3. Routine imaging in $\mathrm{OA}$ follow-up is not III-IV 8.8 (7.9 to 9.7$)$ recommended. However, imaging is recommended if there is unexpected rapid progression of symptoms or change in clinical characteristics to determine if this relates to $\mathrm{OA}$ severity or an additional diagnosis.

4. If imaging is needed, conventional (plain) radiography should be used before other modalities. To make additional diagnoses, soft tissues are best imaged by US or MRI and bone by $\mathrm{CT}$ or MRI.

5. Consideration of radiographic views is important for optimising detection of $\mathrm{OA}$ features; in particular for the knee, weightbearing and patellofemoral views are recommended.

6. According to current evidence, imaging features do not predict non-surgical treatment response and imaging cannot be recommended for this purpose.

7. The accuracy of intra-articular injection depends on the joint and on the skills of the practitioner and imaging may improve accuracy. Imaging is particularly recommended for joints that are difficult to access due to factors including site (eg, hip), degree of deformity and obesity.

Categories of evidence: la, evidence for meta-analysis of randomised controlled trials: $\mathrm{lb}$, evidence from at least one randomised controlled trial; lla, evidence from at least one controlled study without randomisation; Ilb, evidence from at least one other type of quasi-experimental study; III, evidence from non-experimental descriptive studies, such as comparative studies, correlation studies and case-control studies; IV, evidence from expert committee reports or opinions or clinical experience of respected authorities, or both LOA: $0-10$ numerical rating scale.

*Typical features include usage-related pain, short duration morning stiffness, age $>40$ symptoms affecting one or a few joints.

OA, osteoarthritis; US, ultrasonography. 
3. Joint symptoms are also common and increase with age. Symptoms are not always causally related to imaging abnormalities.

4. Full history and examination is always required before considering the need for investigations, including imaging.

5. Modern imaging modalities provide the capability to detect a wide range of soft tissue, bony and cartilage pathology in OA. However, the increased information provided has not yet had any influence on clinical decision-making with respect to management.

\section{Making a diagnosis of $\mathrm{OA}$}

Recommendation 1: Imaging is not required to make the diagnosis in patients with typical ${ }^{[i]}$ presentation of OA.

Level of evidence: III-IV. LOA (95\% CI) 8.7 (7.9 to 9.4)

Although many studies applied imaging for diagnostic purposes, there was a lack of studies in which imaging was applied in addition to clinical findings to evaluate its additional impact on the certainty of diagnosis, which was a predefined criterion for inclusion.

A single study examined the added value of US of hand and feet over clinical findings in a cohort of patients with suspected or confirmed arthritis. When US was added to clinical findings, the diagnostic confidence in differentiating OA from inflammatory arthritis significantly increased. ${ }^{2}$ Due to the absence of strong evidence supporting the use of different imaging modalities at different anatomical sites, the systematic use of imaging in the diagnostic process was not recommended in cases with typical clinical presentation. However, based on the joint site and clinical presentation, imaging might be considered when diagnoses other than OA are suspected. This aspect has been taken into account in Recommendation 2.

Recommendation 2: In atypical presentations, imaging is recommended to help confirm the diagnosis of OA and/or make alternative or additional diagnoses. Level of evidence: IV. LOA (95\% CI) 9.6 (9.1 to 10 )

Studies were eligible for inclusion if they investigated the added value of imaging for differential diagnosis over clinical evaluation. Among studies evaluating the application of imaging for differential diagnosis, no study evaluated the impact of the addition of imaging above clinical findings. The possible application if imaging in atypical clinical scenarios was however recognised by the experts, which included this point in the recommendation.

\section{Monitoring disease}

Recommendation 3: Routine imaging in OA follow-up is not recommended. However, imaging is recommended if there is unexpected rapid progression of symptoms or change in clinical characteristics to determine if this relates to OA severity or an additional diagnosis. Level of evidence: III-IV. LOA (mean, 95\% CI) 8.8 (7.9 to 9.7 )

A specific question addressed the use of imaging for the follow-up. The 117 studies (mostly cohort studies) retrieved covered all joint sites except the foot and all imaging modalities except CT (see online supplementary figure S9). Most of the 83 included studies focused on sensitivity to change. ${ }^{3-86}$ The remaining studies investigated the trajectories of changes of elementary lesions detected by imaging when following OA natural history or described the parallel changes between

'Typical features include usage-related pain, short duration morning stiffness, age $>40$, symptoms affecting one or a few joints. different abnormalities detected by different imaging modalities. $40515387-101$ Only a minority of studies examined the correlation between the change in imaging features and symptoms or relevant clinical outcomes (table 2) and only four US studies evaluated the change of imaging after treatment (see online supplementary file S10). ${ }^{102-111}$

Moreover, there were no studies comparing clinical follow-up with imaging follow-up or strategies adding imaging to clinical management.

The impact of imaging in the management of OA was also specifically addressed by the literature search. Three studies addressed this point. One RCT evaluating the impact of MRI in patients with knee pain assessed in a general practice setting showed that MRI led to an increase in therapeutic confidence but no significant changes in management. ${ }^{112} \mathrm{~A}$ cross-sectional study in an orthopaedic setting investigating the impact of CR over management decisions in knee OA showed that CR led to the change in the opinion in $166 / 400$ cases. ${ }^{113}$ A similar study evaluating the impact of $\mathrm{CR}$ in the assignment of priority for surgery in hip OA showed a relative risk (95\% CI) of $1.98(1.23$ to 3.19) for an earlier assignment in patients with more severe radiographic scores. ${ }^{114}$ No studies evaluated the impact of imaging for the management of hand or foot OA and no studies specifically addressed the issue of non-surgical management.

Recommendation 4: If imaging is needed, conventional (plain) radiography should be used before other modalities. To make additional diagnoses, soft tissues are best imaged by US or MRI and bone by CT or MRI. Level of evidence: III-IV. LOA (95\% CI) 8.7 (7.9 to 9.6$)$

The performance of imaging in the detection of OA elementary lesions was addressed by the SLR and highlighted heterogeneity in the use of imaging modality, lesions considered and reference standard. In fact, physical examination was frequently taken into account as reference standard, while surgery was considered in a minority of studies. Online supplementary file S11 summarises the studies with surgery as the reference standard. ${ }^{115-136}$ As expected, the use of CR was mainly to detect bone and indirectly cartilage loss, MRI was used for bone, cartilage and soft tissues, with a single study assessing US for the evaluation of cartilage.

In general, CR was the imaging modality that was most frequently used for diagnostic, prognostic and follow-up purposes. However, no studies of the cost-effectiveness of each imaging modality or their sequence were found. In the absence of appropriate literature, the experts decided to emphasise the role of the most easily available and less costly imaging modality, proposing as second-level investigations techniques that, due to their characteristics, are more suitable for the detailed assessment of soft tissues (MRI and US) or bone (CT).

Recommendation 5: Consideration of radiographic views is important for optimising detection of OA features; in particular for the knee, weightbearing and patellofemoral views are recommended. Level of evidence: III. LOA (95\% CI) 9.4 (8.7 to 9.9)

This topic was addressed by an additional research question, evaluating the optimal combination of radiographic views in OA. Twenty-seven studies comparing different views for knee OA were included. In this context, all studies involving the tibiofemoral compartment considered weightbearing views, both in extension and various degrees of flexion. $\begin{array}{lllllllll}7 & 8 & 10 & 17 & 25 & 118 & 123 & 137-147 & 188-191\end{array}$ Studies comparing fully extended and flexed views in general showed a moderate to good agreement between the two projections and similar sensitivity and specificity in detecting cartilage damage, considering arthroscopic findings as reference. $^{117} \quad 138 \quad 139148 \quad 149$ The flexed views demonstrated 
superiority in detecting joint space narrowing, a greater sensitivity to change and reproducibility compared with extended views. $^{8} 17140141143144$

Concerning the assessment of the patellofemoral compartment, skyline views had a greater inter-reader and intra-reader reliability and sensitivity to change compared with lateral projections. $^{24} 143144149$ With surgery as reference standard, the skyline view had greater sensitivity and specificity to detect cartilage damage at the patellofemoral joint. ${ }^{150}$

There were five studies assessing the hip. Three studies compared weightbearing and supine anteroposterior (AP) views of the pelvis, one of them showing greater average and maximal

Table 2 Studies correlating changes in imaging findings with symptoms, function or clinical outcome

\begin{tabular}{|c|c|c|c|c|c|c|}
\hline Study & $N$ & Site & $\begin{array}{l}\text { Study } \\
\text { design }\end{array}$ & Imaging & Outcome & \\
\hline Fukui et al., $2010^{103}$ & 68 & Knee & Cohort & $C R$ & $\begin{array}{l}\text { Correlation between radiographic progression } \\
\text { and pain and function scores }\end{array}$ & $\begin{array}{l}\text { Progressors had more pain and disability compared with } \\
\text { non-progressors }\end{array}$ \\
\hline Eckstein et al., $2014^{104}$ & 189 & Knee & $\begin{array}{l}\text { Case- } \\
\text { control }\end{array}$ & MRI & $\begin{array}{l}\text { Cartilage loss in patients undergoing TKA vs } \\
\text { controls }\end{array}$ & $\begin{array}{l}\text { OR }(95 \% \mathrm{Cl}) \text { for cartilage loss in patients undergoing TKA vs } \\
\text { controls: } 1.36 \text { (1.08 to } 1.70)\end{array}$ \\
\hline Kornaat et al., $2007^{105}$ & 182 & Knee & Cohort & MRI & $\begin{array}{l}\text { Change in BMLs/change in WOMAC pain and } \\
\text { function }\end{array}$ & $\begin{array}{l}\text { No significant differences in WOMAC pain and function } \\
\text { depending on the changes of BMLs }\end{array}$ \\
\hline Phan et al., $2006^{106}$ & 34 & Knee & Cohort & MRI & Cartilage and BMLs/WOMAC & $\begin{array}{l}\text { No significant correlation between cartilage loss, BMLs and } \\
\text { WOMAC changes }\end{array}$ \\
\hline Zhang et al., $2011^{107}$ & 651 & Knee & Cohort & MRI & $\begin{array}{l}\text { Change in pain status according to change in } \\
\text { BMLs and effusion/synovitis score }\end{array}$ & $\begin{array}{l}\text { Changes in BMLs and synovitis severity (worsening or } \\
\text { improving) significantly related to the risk of frequent knee } \\
\text { pain ( } p=0.006 \text { for worsening BMLs and } p=0.045 \text { for } \\
\text { improving BMLsNo significant correlation with changes in } \\
\text { effusion severity }\end{array}$ \\
\hline Haugen et al., $2013^{108}$ & 190 & Hand & Cohort & $\mathrm{CR}$ & Radiographic progression/incident tenderness & $\begin{array}{l}\text { Joints with progression had higher odds for tenderness, joints } \\
\text { with incident KLG } 3 \text { or } 4 \text { had higher odds for tenderness }\end{array}$ \\
\hline
\end{tabular}

BMLs, bone marrow lesions; CR, conventional radiography; KLG, Kellgren and Lawrence grade; N, number of participants; TKA, total knee arthroplasty; WOMAC, Western Ontario MacMaster Universities Arthritis Index.

Table 3 Summary of studies evaluating imaging in the prediction of response to treatment: systemic treatment

\begin{tabular}{|c|c|c|c|c|c|c|}
\hline Study & $\mathrm{N}$ & Site & $\begin{array}{l}\text { Study } \\
\text { design }\end{array}$ & Imaging & Outcome & \\
\hline $\begin{array}{l}\text { Gudbergsen et al., } \\
2012^{156}\end{array}$ & 192 & Knee & $\mathrm{RCT}$ & CR MRI & $\begin{array}{l}\text { mJSW, alignment and MRI scores/pain } \\
\text { reduction in response to very-low-energy } \\
\text { diet or low-energy diet }\end{array}$ & $\begin{array}{l}\text { Among all radiographic and MRI parameters, only effusion } \\
\text { score was significantly related to a reduction in pain }\end{array}$ \\
\hline $\begin{array}{l}\text { Gudbergsen et al., } \\
2011^{157}\end{array}$ & 30 & Knee & $\mathrm{RCT}$ & CR MRI & $\begin{array}{l}\text { KLG and MRI score/change in WOMAC pain } \\
\text { and function during weight reduction at } 32 \\
\text { weeks }\end{array}$ & $\begin{array}{l}\text { No significant association between KLG and MRI score and } \\
\text { WOMAC }\end{array}$ \\
\hline $\begin{array}{l}\text { Hellio le Graverand } \\
\text { et al., } 2013^{14}\end{array}$ & 1452 & Knee & $\mathrm{RCT}$ & CR & $\begin{array}{l}\mathrm{KLG} / \text { structural progression in patients } \\
\text { treated with cindunistat or placebo at } 96 \\
\text { weeks }\end{array}$ & $\begin{array}{l}\text { No significant difference between KLG2 and KLG3 in terms of } \\
\text { progression of joint space narrowing in both cindunistat and } \\
\text { placebo group }\end{array}$ \\
\hline Case et al., $2003^{158}$ & 82 & Knee & $\mathrm{RCT}$ & $\mathrm{CR}$ & $\begin{array}{l}\text { KLG and medial JSN/WOMAC response to } \\
\text { diclofenac vs paracetamol at } 12 \text { weeks }\end{array}$ & $\begin{array}{l}\text { Patients with KLG } 1-2 \text { and not } 3-4 \text { and JSN grade } 0-1 \\
\text { compared with } 2 \text { had a better response to diclofenac vs both } \\
\text { placebo and paracetamol }\end{array}$ \\
\hline Sawitzke et al., $2008^{159}$ & 375 & Knee & $\mathrm{RCT}$ & CR & $\begin{array}{l}\text { KLG/radiographic progression during } \\
\text { treatment with glucosamine, chondroitin } \\
\text { sulfate and celecoxib at } 24 \text { months }\end{array}$ & $\begin{array}{l}\text { OR for radiographic progression compared with the placebo } \\
\text { group was }<1 \text { in patients with KLG } 2 \text { knees in all treatment } \\
\text { groups, whereas it was }>1 \text { in patients with KLG } 3 \text { knees in } \\
\text { all treatment groups }\end{array}$ \\
\hline Mazzuca et al., 2010 & 379 & Knee & $\mathrm{RCT}$ & $\mathrm{CR}$ & $\begin{array}{l}\text { Alignment/radiographic progression in } \\
\text { doxycycline vs placebo at } 30 \text { months }\end{array}$ & $\begin{array}{l}\text { Varus knees exhibited a greater loss of JSW than non-varus } \\
\text { knees in patients receiving doxycycline }\end{array}$ \\
\hline Knoop et al., $2014^{164}$ & 91 & Knee & Cohort & MRI & $\begin{array}{l}\mathrm{MRI} / \text { change in WOMAC function in } \\
\text { response to exercise programme at } \\
12 \text { weeks }\end{array}$ & $\begin{array}{l}\text { The severity of the patellofemoral damage was significantly } \\
\text { related to less improvement }\end{array}$ \\
\hline Wenham et al., $2012^{168}$ & 65 & Hand & $\mathrm{RCT}$ & MRI & $\begin{array}{l}\text { MRI/response to prednisolone } 5 \mathrm{mg} \text { at } \\
12 \text { weeks }\end{array}$ & $\begin{array}{l}\text { The baseline number of joints with definite synovitis or } \\
\text { effusion did not correlate with OARSI response }\end{array}$ \\
\hline Lequesne et al., $2002^{84}$ & 163 & Hip & $\mathrm{RCT}$ & CR & $\begin{array}{l}\text { JSW/structural progression in patients } \\
\text { treated with avocado soybean at } 2 \text { years }\end{array}$ & $\begin{array}{l}\text { In patients with smaller JSW treated with avocado soybean, } \\
\text { the reduction of JSW was half than in the placebo group; no } \\
\text { differences in patients with more JSW }\end{array}$ \\
\hline $\begin{array}{l}\text { Rozendaal et al., } \\
2009^{171}\end{array}$ & 222 & Hip & $\mathrm{RCT}$ & CR & $\begin{array}{l}\text { KLG/WOMAC pain and function, JSN in } \\
\text { patients taking glucosamine at } 2 \text { years }\end{array}$ & $\begin{array}{l}\text { Significantly better WOMAC function response in patients } \\
\text { with KLG } 1 \text { compared with KLG 2; no differences in WOMAC } \\
\text { pain and JSN }\end{array}$ \\
\hline Hoeksma et al., $2005^{172}$ & 103 & Hip & $\mathrm{RCT}$ & CR & $\begin{array}{l}\mathrm{KLG} / \text { Harris Hip score and range of motion } \\
\text { in response to manual therapy vs exercise }\end{array}$ & $\begin{array}{l}\text { Better response in terms of range of motion in lower } \\
\text { compared with higher radiographic grades }\end{array}$ \\
\hline
\end{tabular}

CR, conventional radiography; JSN, joint space narrowing; JSW, joint space width; KLG, Kellgren and Lawrence grade; mJSW, minimal joint space width; N, number of participants; OARSI, Osteoarthritis Research Society International; RCT, randomised controlled trial; WOMAC, Western Ontario MacMaster Universities Arthritis Index. 
joint space width detected by the weightbearing view, the remaining showing inconsistent results. ${ }^{151-155}$ Two studies comparing pelvis, hip and oblique views projections in terms of reliability and sensitivity to change demonstrated similar reliability for views dedicated to the hip and views including all the pelvis, with comparable sensitivity to change. ${ }^{72}$ No studies assessing the hand and the foot were found.

\section{Role in prognosis}

Recommendation 6: According to current evidence, imaging features do not predict non-surgical treatment response and imaging cannot be recommended for this purpose. Level of evidence: II-III. LOA (95\% CI) 8.7 (7.5 to 9.7)

Two specific research questions addressed the role of imaging in prognosis, referring to both the prediction of the natural history and to the prediction of non-surgical treatment outcomes. A number of studies addressed the issue of the prognostic value of imaging as predictor of the natural history of OA (see online supplementary figure S12), while only a minority of studies, evaluating all joint sites, investigated the role in predicting treatment response. Due to the heterogeneity in populations, interventions, treatment and study design, a meta-analysis was not possible. In addition, progression of some imaging pathologies may have limited clinical significance. Tables 3 and 4 summarise the results of the 28 primary studies in which imaging was applied to predict treatment response. ${ }^{14} 84$ 156-176 Moreover, an existing SLR was available, without a quantitative synthesis. ${ }^{177}$ The results on the prediction of response were mostly inconsistent across studies; for this reason the use of imaging for this purpose was not recommended.

\section{Treatment (imaging-guided procedures)}

Recommendation 7: The accuracy of intra-articular injection depends on the joint and on the skills of the practitioner and imaging may improve accuracy. Imaging is particularly recommended for joints that are difficult to access due to factors including site (eg, hip), degree of deformity and obesity. Level of evidence: III-IV. LOA (95\% CI) 9.4 (8.9 to 9.9)

A search addressing the impact of imaging to guide intra-articular injections was run specifically for $\mathrm{OA}$ in the beginning. Including only studies comparing imaging-guided to blind procedures, four primary studies were found for the knee and one for the hand, and a qualitative SLR for the knee (table 5). The added value of US was addressed by four studies, while fluoroscopic guidance was tested in a single study. ${ }^{179-183}$

Table 4 Summary of studies evaluating imaging in the prediction of response to treatment: intra-articular treatment

\begin{tabular}{|c|c|c|c|c|c|c|}
\hline Study & $\mathrm{N}$ & Site & $\begin{array}{l}\text { Study } \\
\text { design }\end{array}$ & Imaging & Outcome & \\
\hline Barrett et al., $1990^{178}$ & 248 & Knee & Cohort & $\mathrm{CR}$ & $\begin{array}{l}\text { Radiographic severity/response to } \\
\text { intra-articular HA at } 6 \text { months }\end{array}$ & $\begin{array}{l}\text { Patients with less severe radiographic grade had a better } \\
\text { response in terms of pain at rest, at walking and at night }\end{array}$ \\
\hline Gaffney, $1995^{189}$ & 84 & Knee & $\mathrm{RCT}$ & $\mathrm{CR}$ & $\begin{array}{l}\text { OA severity } 0-3 / \text { response to intra-articular } \\
\text { triamcinolone vs placebo at } 3 \text { weeks }\end{array}$ & $\begin{array}{l}\text { No association between improvement in VAS pain and } \\
\text { radiographic score }\end{array}$ \\
\hline Toh et al., $2002^{161}$ & 60 & Knee & Cohort & $C R$ & $\begin{array}{l}\text { Alignment, sclerosis, cysts, osteophytes, } \\
\text { JSN/WOMAC response to intra-articular HA } \\
\text { at } 12 \text { weeks }\end{array}$ & $\begin{array}{l}\text { Patients with lateral and medial JSN had less WOMAC } \\
\text { response compared with patients without }\end{array}$ \\
\hline Pendleton et al., $2008^{176}$ & 86 & Knee & Cohort & US & $\begin{array}{l}\text { US/WOMAC response to intra-articular } \\
\text { methylprednisolone }\end{array}$ & $\begin{array}{l}\text { Higher baseline US scores: significant improvements in all } \\
\text { WOMAC subscales at } 1 \text { and } 6 \text { weeks }\end{array}$ \\
\hline Chao et al., $2010^{162}$ & 67 & Knee & $\mathrm{RCT}$ & US & $\begin{array}{l}\text { US inflammation/WOMAC response to } \\
\text { triamcinolone at } 12 \text { weeks }\end{array}$ & $\begin{array}{l}\text { Statistically significant improvement in pain subscales among } \\
\text { without inflammatory abnormalities at US patients compared } \\
\text { with the remaining patients }\end{array}$ \\
\hline $\begin{array}{l}\text { Anandacoomarasamy } \\
\text { et al., } 2008^{163}\end{array}$ & 32 & Knee & Cohort & MRI & $\begin{array}{l}\text { Cartilage volume/response to intra-articular } \\
\mathrm{HA} \text { at } 6 \text { months }\end{array}$ & $\begin{array}{l}\text { No correlation between baseline MRI measures and clinical } \\
\text { response }\end{array}$ \\
\hline Drakonaki, $2011^{190}$ & 51 & Foot & Cohort & CR US & $\begin{array}{l}\text { Positive therapeutic response } \\
\text { (intra-articular. methylprednisolone) at } \\
12 \text { months }\end{array}$ & $\begin{array}{l}\text { No differences in terms of response in patients showing } \\
\text { degenerative changes only on US and those showing changes } \\
\text { in both US and CR }\end{array}$ \\
\hline Han et al., $2014^{165}$ & 40 & Foot & Cohort & $C R$ & $\begin{array}{l}\text { Response to intra-articular HA (VAS pain) } \\
\text { at } 12 \text { months }\end{array}$ & $\begin{array}{l}\text { Patients with early radiographic stage had a better response } \\
\text { compared with those with advanced radiographic stage at } 3 \\
\text { and } 6 \text { months, but not at } 12 \text { months }\end{array}$ \\
\hline Sun et al., $2011^{166}$ & 46 & Foot & Cohort & $\mathrm{CR}$ & $\begin{array}{l}\text { KLG } 2 \text { and 3/AOS, AOFAS scores in } \\
\text { response to intra-articular HA }\end{array}$ & $\begin{array}{l}\text { No significant difference in the AOS, AOFAS or clinical } \\
\text { balance test scores between KLG } 2 \text { and } 3 \text { at any time point }\end{array}$ \\
\hline Mallinson et al., $2013^{167}$ & 31 & Hand & Cohort & CR US & $\begin{array}{l}\mathrm{CR} \text { and US/response to intra-articular } \\
\text { triamcinolone at } 6 \text { weeks }\end{array}$ & $\begin{array}{l}\text { No significant association between treatment response and } \\
\text { grade for osteophytes, joint space narrowing and capsule } \\
\text { thickness }\end{array}$ \\
\hline Atchia et al., $2011^{169}$ & 77 & Hip & $\mathrm{RCT}$ & US & $\begin{array}{l}\text { Synovitis/response to intra-articular } \\
\text { methylprednisolone at } 6 \text { weeks }\end{array}$ & The presence of synovitis significantly predicted the response \\
\hline $\begin{array}{l}\text { Rennesson-Rey et al., } \\
2008^{170}\end{array}$ & 55 & Hip & Cohort & CR US & $\begin{array}{l}\text { Effusion and KLG/OARSI response to } \mathrm{HA} \text { at } \\
6 \text { months }\end{array}$ & $\begin{array}{l}\text { Patients with KLG } 1-2 \text { had a better } 1 \text { month response } \\
\text { compared with grades } 3-4 \text {; non-differences at } 3 \text { and } \\
6 \text { months, no differences in patients with or without effusion }\end{array}$ \\
\hline Deshmukh et al., $2011^{173}$ & 220 & Hip & Cohort & $\mathrm{CR}$ & $\begin{array}{l}\text { KLG/pain relief after methylprednisolone } \\
\text { injections at } 2 \text { weeks }\end{array}$ & $\begin{array}{l}\text { Patients with KLG 3-4 had more frequently delayed relief } \\
\text { compared with KLG } 2\end{array}$ \\
\hline Robinson et al., $2007^{175}$ & 120 & Hip & Cohort & CR US & $\begin{array}{l}\text { US osteophytes and capsular thickening, } \\
\text { KLG/WOMAC response to intra-articular CS } \\
\text { at } 12 \text { weeks }\end{array}$ & $\begin{array}{l}\text { No baseline US or radiographic variable predictive of the } \\
\text { outcome }\end{array}$ \\
\hline
\end{tabular}

AOFAS, Australian Orthopedic Foot and ankle society; AOS, ankle osteoarthritis score; CR, conventional radiography; CS, corticosteroids; HA, hyaluronic acid; JSN, joint space narrowing; KLG, Kellgren and Lawrence grade; N, number of participants; OA, osteoarthritis; OARSI, Osteoarthritis Research Society International; RCT, randomised controlled trial; US, ultrasonography; VAS, visual analogue scale; WOMAC, Western Ontario MacMaster Universities Arthritis Index. 
Table 5 Studies comparing imaging-guided to blind injections in $\mathrm{OA}$

\begin{tabular}{|c|c|c|c|c|c|c|}
\hline Study & $\mathrm{N}$ & Site & $\begin{array}{l}\text { Study } \\
\text { design }\end{array}$ & Imaging & Outcome & \\
\hline Bum Park, $2012^{191}$ & 99 & Knee & RCT & US & Accuracy of HA injection vs blind injection & $\begin{array}{l}\text { OR }(95 \% \mathrm{Cl}) \text { for an accurate injection with US compared } \\
\text { with blind: } 4.68 \text { (0.94 to } 23.30)\end{array}$ \\
\hline Im et al., $2009^{179}$ & 99 & Knee & RCT & US & Accuracy of HA injection vs blind injection & $\begin{array}{l}\text { Accurate injections: } 95.5 \% \text { (US-guided) vs } 77.2 \% \text { (blind); } \\
\mathrm{p}=0.01\end{array}$ \\
\hline Jang et al., $2013^{180}$ & 126 & Knee & RCT & US & $\begin{array}{l}\text { Accuracy of US-guided in plain injection, } \\
\text { US-guided out-of-plane injections and blind } \\
\text { injection of triamcinolone hexacetonide }\end{array}$ & $\begin{array}{l}\text { Accuracy: US-guided in plain } 95.1 \% \text {; US-guided } \\
\text { out-of-plain } 97.7 \% \text {; blind } 78 \% \\
\text { p }<0.05 \text { blind vs US-guided injections }\end{array}$ \\
\hline Sibbitt et al., $2011^{181}$ & 92 & Knee & RCT & US & $\begin{array}{l}\text { US-guided vs blind triamcinolone in terms of } \\
\text { pain relief, pain related to the injection, } \\
\text { reinjection rate and cost }\end{array}$ & $\begin{array}{l}\text { Significant decrease in pain only in patients treated with } \\
\text { US-guided injection; US-guided procedure was related to } \\
\text { lower pain and reinjection rate, but higher costs }\end{array}$ \\
\hline Karalezli et al., $2007^{182}$ & 16 & Hand & Cohort & $C R$ & $\begin{array}{l}\text { Fluoroscopy-guided vs blind injections of HA in } \\
\text { the trapezio-metacarpal joint in terms of pain } \\
\text { related to the injection }\end{array}$ & $\begin{array}{l}\text { VAS pain related to the procedure: fluoroscopic guide: } 4.1 \\
\text { (range 3-6), anatomic guide } 5.6 \text { (range 3-7); } p<0.005 \\
\text { No significant difference in terms of safety }\end{array}$ \\
\hline
\end{tabular}

$\mathrm{CR}$, conventional radiography; $\mathrm{HA}$, hyaluronic acid; N, number of participants; $\mathrm{OA}$, osteoarthritis; $\mathrm{RCT}$, randomised controlled trial; US, ultrasonography; VAS, visual analogue scale.

In order to retrieve further information on this topic, an additional search was performed (see online supplementary file S1 for search strategies), including studies comparing blind to guided injections in OA and also in other conditions. This search found eight studies, of which three were already included in the previous results (see online supplementary file S13). ${ }^{184-188}$ Most of the studies were focused on the knee, with some studies on the hand and the foot, while no studies were found for the hip. All the additional studies investigated the impact of US. Accuracy was found to be better in imaging guided compared with blind procedures; however, the results on the clinical outcomes of the injection were less consistent across studies. For these reasons, the systematic use of imaging to drive injections was not recommended, leaving this tool to drive injection in specific situations, identified by the experts. Although the imaging modality is not specified in the recommendation, there is published evidence for the use of US, and imaging allows for realtime evaluation of injection placement.

\section{Future research agenda}

The most important topics to drive future research were selected by the Task Force based on the (often considerable) gaps in the evidence and the needs arising from clinical practice (table 6).

\section{DISCUSSION}

Although a number of recommendations have been made on how to use imaging in OA clinical trials, these are the first recommendations on the use of imaging in $\mathrm{OA}$ in clinical practice. The development of the recommendations started from questions of clinical relevance selected by a task force of experts, with the aim to focus on topics of interest for clinical practice rather than research. The literature review identified a large number of studies, covering most joint sites. However, a possible limitation of this work is that we used a search term of 'osteoarthritis' and not 'pain', and it is possible we missed studies that imaged painful sites without specifically mentioning $\mathrm{OA}$; this may explain the paucity of foot pain studies included. Although CR was still the most frequently applied technique, a substantial number of studies focused on modern imaging, MRI and US in particular.

However, despite the amount of data available in the literature, only a small part of this information was relevant for clinical practice. For this reason, many areas needing further investigation were identified. In particular, there was a lack of strategic studies investigating the additional value of imaging
Table 6 Future research agenda

1 There is a need for methodologically robust studies to explore the added value of imaging (any modality) to clinical diagnosis or differential diagnosis.

2 What is the cost-effectiveness of imaging in osteoarthritis clinical practice?

3 Is imaging able to help in identification of subgroups/phenotypes that may have different trajectories and enable targeted treatment based on these subgroups?

4 There is a need to understand if using imaging to measure response to therapy is of clinical benefit. This may require evaluation of novel imaging technologies that are able to sensitively detect change in relevant joint structures.

5 Quality studies are required to explore imaging (any modality) features that predict response to specific therapies.

6 There is a need for more research concerning the benefits of imaging in less commonly studied osteoarthritis sites such as the foot and shoulder.

7 Specifically for hip osteoarthritis, what is the added value of weightbearing vs non-weightbearing $\mathrm{X}$-rays?

8 What are the benefits of imaging guidance in improving the efficacy of treatments?

over clinical findings in making a diagnosis of OA, in the management and the follow-up of the disease, and inconsistent results dealing with the prediction of the outcome of non-pharmacological treatments. The absence of good study information in these areas did not enable the Task Force to recommend systematic imaging in all these areas. A research agenda was therefore generated in order to address these topics in the future research.

In conclusion, seven recommendations covering different areas in the routine management of OA were developed. These are based on both available scientific evidence and expert opinion to provide a valuable and sensible guide for the use of imaging in clinical practice.

\section{Author affiliations}

${ }^{1}$ Division of Rheumatology, IRCCS Policlinico San Matteo Foundation, University of Pavia, Pavia, Italy

${ }^{2}$ Leeds Institute of Rheumatic and Musculoskeletal Medicine, University of Leeds and National Institute of Health Research Leeds Musculoskeletal Biomedical Research Unit, Leeds, UK

${ }^{3}$ Academic Rheumatology, Clinical Sciences Building, University of Nottingham, Nottingham City Hospital, Nottingham, UK

${ }^{4}$ Department of Rheumatology \& Clinical Immunology, University Medical Center Utrecht, Utrecht, The Netherlands

${ }^{5}$ Department of Rheumatology, Diakonhjemmet Hospital, Oslo, Norway

${ }^{6}$ APHP, Hôpital Ambroise Paré, Service de Rhumatologie, Boulogne-Billancourt, France 
${ }^{7}$ INSERM U1173, Laboratoire d'Excellence INFLAMEX, Université Paris OuestVersailles St.-Quentin, Saint Quentin en Yvelines, France

${ }^{8}$ 2nd Internal Medicine Department, "Iuliu Hațieganu" University of Medicine and Pharmacy, Cluj-Napoca, Romania

${ }^{9}$ Department of Rheumatology, Leiden University Medical Center (LUMC), Leiden, The Netherlands

${ }^{10}$ Department of Diagnostic and Interventional Radiology, Medical Faculty, University Dusseldorf, Dusseldorf, Germany

${ }^{11}$ Department of Rheumatology, Hospital General Universitario Gregorio Marañón, Madrid, Spain

${ }^{12}$ Research Institute for Primary Care and Health Sciences, Keele University, Keele, UK

${ }^{13}$ Rheumatology Unit, Dipartimento di Scienze Cliniche e Blologiche, Università degli Studi di Torino, Turin, Italy

Acknowledgements The authors thank Mrs Jaqueline Mäder for participating to the development of the recommendations.

Contributors GS and PGC contributed equally. GS performed the literature review, GS and PGC produced drafts of the manuscript with advice from Al and WZ. All authors were involved in the production of the recommendations and have reviewed the final manuscript.

Funding The authors would like to thank EULAR for financial support for this work. PGC is supported in part by the National Institute for Health Research (NIHR) Leeds Musculoskeletal Biomedical Research Unit.

Disclaimer The views expressed are those of the author(s) and not necessarily those of the NHS, the NIHR or the Department of Health.

\section{Competing interests None.}

Provenance and peer review Not commissioned; externally peer reviewed.

\section{REFERENCES}

1 Petron DJ, Greis PE, Aoki SK, et al. Use of knee magnetic resonance imaging by primary care physicians in patients aged 40 years and older. Sports Health 2010:2:385-90

2 Matsos M, Harish S, Zia P, et al. Ultrasound of the hands and feet for rheumatological disorders: influence on clinical diagnostic confidence and patient management. Skeletal Radiol 2009;38:1049-54.

3 Wirth W, Nevitt M, Hellio Le Graverand MP, et al. Lateral and medial joint space narrowing predict subsequent cartilage loss in the narrowed, but not in the non-narrowed femorotibial compartment--data from the Osteoarthritis Initiative. Osteoarthritis Cartilage 2014;22:63-70.

4 Pessis E, Drapé JL, Ravaud P, et al. Assessment of progression in knee osteoarthritis: results of a 1 year study comparing arthroscopy and MRI. Osteoarthritis Cartilage 2003;11:361-9.

5 Conrozier T, Mathieu P, Piperno M, et al. Selection of knee radiographs for trials of structure-modifying drugs in patients with knee osteoarthritis: a prospective, longitudinal study of Lyon schuss knee radiographs with the definition of adequate alignment of the medial tibial plateau. Arthritis Rheum 2005;52:1411-17.

6 Le Graverand MP, Vignon EP, Brandt KD, et al. Head-to-head comparison of the Lyon Schuss and fixed flexion radiographic techniques. Long-term reproducibility in normal knees and sensitivity to change in osteoarthritic knees. Ann Rheum Dis 2008:67:1562-6.

7 Mazzuca SA, Hellio Le Graverand MP, Vignon E, et al. Performance of a non-fluoroscopically assisted substitute for the Lyon schuss knee radiograph: quality and reproducibility of positioning and sensitivity to joint space narrowing in osteoarthritic knees. Osteoarthritis Cartilage 2008;16:1555-9.

8 Piperno M, Hellio Le Graverand MP, Conrozier T, et al. Quantitative evaluation of joint space width in femorotibial osteoarthritis: comparison of three radiographic views. Osteoarthritis Cartilage 1998:6:252-9.

9 Spector TD, Conaghan PG, Buckland-Wright JC, et al. Effect of risedronate on joint structure and symptoms of knee osteoarthritis: results of the BRISK randomized, controlled trial [ISRCTN01928173]. Arthritis Res Ther 2005;7: R625-33.

10 Mazzuca SA, Brandt KD, Buckwalter KA. Detection of radiographic joint space narrowing in subjects with knee osteoarthritis: longitudinal comparison of the metatarsophalangeal and semiflexed anteroposterior views. Arthritis Rheum 2003;48:385-90.

11 Botha-Scheepers S, Kloppenburg M, Kroon HM, et al. Fixed-flexion knee radiography: the sensitivity to detect knee joint space narrowing in osteoarthritis. Osteoarthritis Cartilage 2007;15:350-3.

12 Cicuttini FM, Wluka AE, Hankin J, et al. Comparison of patella cartilage volume and radiography in the assessment of longitudinal joint change at the patellofemoral joint. J Rheumatol 2004;31:1369-72.

13 Hellio Le Graverand MP, Buck RJ, Wyman BT, et al. Change in regional cartilage morphology and joint space width in osteoarthritis participants versus healthy controls: a multicentre study using 3.0 Tesla MRI and Lyon-Schuss radiography. Ann Rheum Dis 2010:69:155-62.

14 Hellio le Graverand MP, Clemmer RS, Redifer P, et al. A 2-year randomised, double-blind, placebo-controlled, multicentre study of oral selective iNOS inhibitor, cindunistat (SD-6010), in patients with symptomatic osteoarthritis of the knee. Ann Rheum Dis 2013:72:187-95.

15 Mazzuca SA, Brandt KD, Dieppe PA, et al. Effect of alignment of the medial tibial plateau and $\mathrm{x}$-ray beam on apparent progression of osteoarthritis in the standing anteroposterior knee radiograph. Arthritis Rheum 2001;44:1786-94.

16 Pavelka K, Forejtová S, Olejarová M, et al. Hyaluronic acid levels may have predictive value for the progression of knee osteoarthritis. Osteoarthritis Cartilage 2004;12:277-83.

17 Vignon E, Piperno M, Le Graverand MPH, et al. Measurement of radiographic joint space width in the tibiofemoral compartment of the osteoarthritic knee: comparison of standing anteroposterior and Lyon schuss views. Arthritis Rheum 2003;48:378-84.

18 Wirth W, Duryea J, Hellio Le Graverand MP, et al. Direct comparison of fixed flexion, radiography and MRI in knee osteoarthritis: responsiveness data from the Osteoarthritis Initiative. Osteoarthritis Cartilage 2013:21:117-25.

19 Boegård TL, Rudling 0 , Petersson IF, et al. Distribution of MR-detected cartilage defects of the patellofemoral joint in chronic knee pain. Osteoarthritis Cartilage 2003:11:494-8.

20 Mazzuca SA, Brandt KD, Buckwalter KA, et al. Pitfalls in the accurate measurement of joint space narrowing in semiflexed, anteroposterior radiographic imaging of the knee. Arthritis Rheum 2004;50:2508-15.

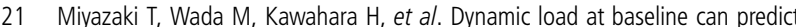
radiographic disease progression in medial compartment knee osteoarthritis. Ann Rheum Dis 2002:61:617-22.

22 Bruyère $\mathrm{O}$, Henrotin $\mathrm{YE}$, Honoré $\mathrm{A}$, et al. Impact of the joint space width measurement method on the design of knee osteoarthritis studies. Aging Clin Exp Res 2003;15:136-41.

23 Gossec L, Jordan JM, Mazzuca SA, et al. Comparative evaluation of three semi-quantitative radiographic grading techniques for knee osteoarthritis in terms of validity and reproducibility in 1759 X-rays: report of the OARSI-OMERACT task force. Osteoarthritis Cartilage 2008;16:742-8.

24 Lanyon P, Jones A, Doherty M. Assessing progression of patellofemoral osteoarthritis: a comparison between two radiographic methods. Ann Rheum Dis 1996;55:875-9.

25 LaValley MP, McLaughlin S, Goggins J, et al. The lateral view radiograph for assessment of the tibiofemoral joint space in knee osteoarthritis: its reliability, sensitivity to change, and longitudinal validity. Arthritis Rheum 2005;52:3542-7.

26 Nevitt MC, Peterfy C, Guermazi A, et al. Longitudinal performance evaluation and validation of fixed-flexion radiography of the knee for detection of joint space loss. Arthritis Rheum 2007:56:1512-20.

27 Reginster JY, Deroisy R, Rovati LC, et al. Long-term effects of glucosamine sulphate on osteoarthritis progression: a randomised, placebo-controlled clinical trial. Lancet 2001;357:251-6.

28 Sugiyama S, Itokazu M, Suzuki Y, et al. Procollagen II C propeptide level in the synovial fluid as a predictor of radiographic progression in early knee osteoarthritis Ann Rheum Dis 2003:62:27-32.

29 Reichmann WM, Katz JN, Losina E. Differences in self-reported health in the osteoarthritis Initiative (OAI) and Third national health and nutrition Examination survey (NHANES-III). PLOS ONE 2011;6:e17345.

30 Duryea J, Neumann G, Niu J, et al. Comparison of radiographic joint space width with magnetic resonance imaging cartilage morphometry: analysis of longitudinal data from the osteoarthritis initiative. Arthritis Care Res (Hoboken) 2010;62:932-7.

31 Eckstein F, Maschek S, Wirth W, et al. One year change of knee cartilage morphology in the first release of participants from the Osteoarthritis Initiative progression subcohort: association with sex, body mass index, symptoms and radiographic osteoarthritis status. Ann Rheum Dis 2009;68:674-9.

32 Eckstein F, Wirth W, Hudelmaier MI, et al. Relationship of compartment-specific structural knee status at baseline with change in cartilage morphology: a prospective observational study using data from the osteoarthritis initiative. Arthritis Res Ther 2009:11:R90.

33 Eckstein F, Buck RJ, Burstein D, et al. Precision of 3.0 Tesla quantitative magnetic resonance imaging of cartilage morphology in a multicentre clinical trial. Ann Rheum Dis 2008;67:1683-8.

34 Eckstein F, Benichou 0, Wirth W, et al. Magnetic resonance imaging-based cartilage loss in painful contralateral knees with and without radiographic joint space narrowing: data from the osteoarthritis initiative. Arthritis Rheum 2009:61:1218-25

35 Blumenkrantz G, Lindsey CT, Dunn TC, et al. A pilot, two-year longitudinal study of the interrelationship between trabecular bone and articular cartilage in the osteoarthritic knee. Osteoarthritis Cartilage 2004;12:997-1005.

36 Eckstein F, Nevitt M, Gimona A, et al. Rates of change and sensitivity to change in cartilage morphology in healthy knees and in knees with mild, moderate, and end-stage radiographic osteoarthritis: results from 831 participants from the Osteoarthritis Initiative. Arthritis Care Res (Hoboken) 2011;63:311-19. 
37 Hunter DJ, Niu J, Zhang Y, et al. Change in cartilage morphometry: a sample of the progression cohort of the Osteoarthritis Initiative. Ann Rheum Dis 2009;68:349-56.

38 Hunter DJ, Li L, Zhang YQ, et al. Region of interest analysis: by selecting regions with denuded areas can we detect greater amounts of change? Osteoarthritis Cartilage 2010;18:175-83.

39 Maschek S, Wirth W, Ladel C, et al. Rates and sensitivity of knee cartilage thickness loss in specific central reading radiographic strata from the osteoarthritis initiative. Osteoarthritis Cartilage 2014;22:1550-3.

40 Cromer MS, Bourne RM, Fransen M, et al. Responsiveness of quantitative cartilage measures over one year in knee osteoarthritis: comparison of radiography and MRI assessments. J Magne Reson Imaging 2014;39:103-9.

41 Buck RJ, Wyman BT, Le Graverand MP, et al. Osteoarthritis may not be a one-wayroad of cartilage loss--comparison of spatial patterns of cartilage change between osteoarthritic and healthy knees. Osteoarthritis Cartilage 2010;18:329-35.

42 Eckstein F, Kunz M, Schutzer M, et al. Two year longitudinal change and test-retest-precision of knee cartilage morphology in a pilot study for the osteoarthritis initiative. Osteoarthritis Cartilage 2007;15:1326-32.

43 Hudelmaier M, Wirth W, Wehr B, et al. Femorotibial cartilage morphology: reproducibility of different metrics and femoral regions, and sensitivity to change in disease. Cells Tissues Organs 2010;192:340-50.

44 Iranpour-Boroujeni T, Watanabe A, Bashtar R, et al. Quantification of cartilage loss in local regions of knee joints using semi-automated segmentation software: analysis of longitudinal data from the Osteoarthritis Initiative (OAI). Osteoarthritis Cartilage 2011;19:309-14.

45 Raynauld JP, Martel-Pelletier J, Berthiaume MJ, et al. Quantitative magnetic resonance imaging evaluation of knee osteoarthritis progression over two years and correlation with clinical symptoms and radiologic changes. Arthritis Rheum 2004;50:476-87.

46 Raynauld JP, Martel-Pelletier J, Berthiaume MJ, et al. Long term evaluation of disease progression through the quantitative magnetic resonance imaging of symptomatic knee osteoarthritis patients: correlation with clinical symptoms and radiographic changes. Arthritis Res Ther 2006;8:R21.

47 Raynauld JP, Martel-Pelletier J, Berthiaume MJ, et al. Correlation between bone lesion changes and cartilage volume loss in patients with osteoarthritis of the knee as assessed by quantitative magnetic resonance imaging over a 24-month period. Ann Rheum Dis 2008;67:683-8.

48 Raynauld JP, Martel-Pelletier J, Abram F, et al. Analysis of the precision and sensitivity to change of different approaches to assess cartilage loss by quantitative MRI in a longitudinal multicentre clinical trial in patients with knee osteoarthritis. Arthritis Res Ther 2008;10:R129.

49 Raynauld JP, Martel-Pelletier J, Bias P, et al. Protective effects of licofelone, a 5 -lipoxygenase and cyclo-oxygenase inhibitor, versus naproxen on cartilage loss in knee osteoarthritis: a first multicentre clinical trial using quantitative MRI. Ann Rheum Dis 2009;68:938-47.

50 Eckstein F, Mc Culloch CE, Lynch JA, et al. How do short-term rates of femorotibial cartilage change compare to long-term changes? Four year follow-up data from the osteoarthritis initiative. Osteoarthritis Cartilage 2012:20:1250-7.

51 Amin S, LaValley MP, Guermazi A, et al. The relationship between cartilage loss on magnetic resonance imaging and radiographic progression in men and women with knee osteoarthritis. Arthritis Rheum 2005;52:3152-9.

52 Gandy SJ, Dieppe PA, Keen MC, et al. No loss of cartilage volume over three years in patients with knee osteoarthritis as assessed by magnetic resonance imaging. Osteoarthritis Cartilage 2002;10:929-37.

53 Hunter DJ, Zhang Y, Niu J, et al. Increase in bone marrow lesions associated with cartilage loss: a longitudinal magnetic resonance imaging study of knee osteoarthritis. Arthritis Rheum 2006;54:1529-35.

54 Pelletier JP, Raynauld JP, Abram F, et al. A new non-invasive method to assess synovitis severity in relation to symptoms and cartilage volume loss in knee osteoarthritis patients using MRI. Osteoarthritis Cartilage 2008;16(Suppl 3):S8-13.

55 Brandt KD, Mazzuca SA, Buckwalter KA. Acetaminophen, like conventional NSAIDs, may reduce synovitis in osteoarthritic knees. Rheumatology (Oxford) 2006;45:1389-94.

56 Hunter DJ, Conaghan PG, Peterfy CG, et al. Responsiveness, effect size, and smallest detectable difference of Magnetic Resonance Imaging in knee osteoarthritis. Osteoarthritis Cartilage 2006;14(Suppl A):A112-15.

57 Hunter DJ, Zhang W, Conaghan PG, et al. Responsiveness and reliability of MRI in knee osteoarthritis: a meta-analysis of published evidence. Osteoarthritis Cartilage 2011;19:589-605

58 Stahl R, Blumenkrantz G, Carballido-Gamio J, et al. MRI-derived T2 relaxation times and cartilage morphometry of the tibio-femoral joint in subjects with and without osteoarthritis during a 1-year follow-up. Osteoarthritis Cartilage 2007;15:1225-34

59 Wirth W, Hellio Le Graverand MP, Wyman BT, et al. Regional analysis of femorotibial cartilage loss in a subsample from the Osteoarthritis Initiative progression subcohort. Osteoarthritis Cartilage 2009;17:291-7.

60 Wirth W, Buck R, Nevitt M, et al. MRI-based extended ordered values more efficiently differentiate cartilage loss in knees with and without joint space narrowing than region-specific approaches using MRI or radiography--data from the OA initiative. Osteoarthritis Cartilage 2011;19:689-99.

61 Wirth W, Benichou 0, Kwoh CK, et al. Spatial patterns of cartilage loss in the medial femoral condyle in osteoarthritic knees: data from the Osteoarthritis Initiative. Magn Reson Med 2010;63:574-81.

62 Creamer $\mathrm{P}$, Sharif M, George E, et al. Intra-articular hyaluronic acid in osteoarthritis of the knee: an investigation into mechanisms of action. Osteoarthritis Cartilage 1994:2:133-40.

63 Hall M, Doherty S, Courtney $P$, et al. Ultrasound detected synovial change and pain response following intra-articular injection of corticosteroid and a placebo in symptomatic osteoarthritic knees: a pilot study. Ann Reum Dis 2014;73:1590-1.

64 Song IH, Althoff CE, Hermann KG, et al. Contrast-enhanced ultrasound in monitoring the efficacy of a bradykinin receptor 2 antagonist in painful knee osteoarthritis compared with MRI. Ann Rheum Dis 2009;68:75-83.

65 Hall M, Doherty S, Courtney P, et al. Synovial pathology detected on ultrasound correlates with the severity of radiographic knee osteoarthritis more than with symptoms. Osteoarthritis Cartilage 2014;22:1627-33.

66 Botha-Scheepers S, Riyazi N, Watt I, et al. Progression of hand osteoarthritis over 2 years: a clinical and radiological follow-up study. Ann Rheum Dis 2009;68:1260-4.

67 Botha-Scheepers S, Watt I, Breedveld FC, et al. Reading radiographs in pairs or in chronological order influences radiological progression in osteoarthritis. Rheumatology (Oxford) 2005;44:1452-5.

68 Maheu E, Cadet C, Gueneugues S, et al. Reproducibility and sensitivity to change of four scoring methods for the radiological assessment of osteoarthritis of the hand. Ann Rheum Dis 2007;66:464-9.

69 Buckland-Wright JC, Macfarlane DG, Lynch JA. Osteophytes in the osteoarthritic hand: their incidence, size, distribution, and progression. Ann Rheum Dis 1991;50:627-30.

70 Auleley GR, Giraudeau B, Dougados M, et al. Radiographic assessment of hip osteoarthritis progression: impact of reading procedures for longitudinal studies. Ann Rheum Dis 2000;59:422-7.

71 Botha-Scheepers S, Watt I, Rosendaal FR, et al. Changes in outcome measures for impairment, activity limitation, and participation restriction over two years in osteoarthritis of the lower extremities. Arthritis Rheum 2008;59:1750-5.

72 Conrozier T, Brandt $\mathrm{K}$, Piperno $\mathrm{M}$, et al. Reproducibility and sensitivity to change of a new method of computer measurement of joint space width in hip osteoarthritis. Performance of three radiographic views obtained at a 3-year interval. Osteoarthritis Cartilage 2009;17:864-70.

73 Conrozier T, Saxne T, Fan CSS, et al. Serum concentrations of cartilage oligomeric matrix protein and bone sialoprotein in hip osteoarthritis: A one year prospective study. Ann Rheum Dis 1998;57:527-32.

74 Dougados $M$, Nguyen $M$, Berdah $L$, et al. Evaluation of the structure-modifying effects of diacerein in hip osteoarthritis: ECHODIAH, a three-year, placebo-controlled trial. Evaluation of the Chondromodulating Effect of Diacerein in OA of the Hip. Arthritis Rheum 2001;44:2539-47.

75 Maheu E, Cadet C, Marty M, et al. Reproducibility and sensitivity to change of various methods to measure joint space width in osteoarthritis of the hip: a double reading of three different radiographic views taken with a three-year interval. Arthritis Res Ther 2005;7:R1375-85.

76 Maillefert JF, Sharp JT, Aho LS, et al. Comparison of a computer based method and the classical manual method for radiographic joint space width assessment in hip osteoarthritis. J Rheumatol 2002;29:2592-6.

77 Papaloucas CD, Ward RJ, Tonkin CJ, et al. Cancellous bone changes in hip osteoarthritis: a short-term longitudinal study using fractal signature analysis. Osteoarthritis Cartilage 2005;13:998-1003.

78 Pavelká K, Gatterová J, Gollerova V, et al. A 5-year randomized controlled, double-blind study of glycosaminoglycan polysulphuric acid complex (Rumalon) as a structure modifying therapy in osteoarthritis of the hip and knee. Osteoarthritis Cartilage 2000;8:335-42.

79 Ratzlaff C, Van Wyngaarden C, Duryea J. Location-specific hip joint space width for progression of hip osteoarthritis-data from the Osteoarthritis Initiative. Osteoarthritis Cartilage 2014;22:1481-7.

80 Jaremko JL, Lambert RG, Zubler V, et al. Methodologies for semiquantitative evaluation of hip osteoarthritis by magnetic resonance imaging: approaches based on the whole organ and focused on active lesions. J Rheumatol 2014;41:359-69.

81 Conrozier T, Jousseaume CA, Mathieu P, et al. Quantitative measurement of joint space narrowing progression in hip osteoarthritis: a longitudinal retrospective study of patients treated by total hip arthroplasty. Br J Rheumatol 1998;37:961-8.

82 Maillefert JF, Gueguen A, Nguyen M, et al. Relevant change in radiological progression in patients with hip osteoarthritis. I. Determination using predictive validity for total hip arthroplasty. Rheumatology (Oxford) 2002;41:142-7.

83 Gossec L, Jordan JM, Lam MA, et al. Comparative evaluation of three semi-quantitative radiographic grading techniques for hip osteoarthritis in terms of validity and reproducibility in 1404 radiographs: report of the OARSI-OMERACT Task Force. Osteoarthritis Cartilage 2009;17:182-7.

84 Lequesne M, Maheu E, Cadet C, et al. Structural effect of avocado/soybean unsaponifiables on joint space loss in osteoarthritis of the hip. Arthritis Rheum 2002;47:50-8. 
85 Dougados M, Gueguen A, Nguyen M, et al. Radiological progression of hip osteoarthritis: definition, risk factors and correlations with clinical status. Ann Rheum Dis 1996;55:356-62.

86 lagnocco A, Filippucci $\mathrm{E}$, Riente $\mathrm{L}$, et al. Ultrasound imaging for the rheumatologist XLI. Sonographic assessment of the hip in OA patients. Clin Exp Rheumatol 2012:30:652-7.

87 Felson DT, Parkes MJ, Marjanovic EJ, et al. Bone marrow lesions in knee osteoarthritis change in 6-12 weeks. Osteoarthritis Cartilage 2012:20:1514-8.

88 Hunter DJ, Bowes MA, Eaton CB, et al. Can cartilage loss be detected in knee osteoarthritis (OA) patients with 3-6 months' observation using advanced image analysis of 3T MRI. Osteoarthritis Cartilage 2010;18:677-83.

89 Stahl R, Jain SK, Lutz J, et al. Osteoarthritis of the knee at 3.0 T: comparison of a quantitative and a semi-quantitative score for the assessment of the extent of cartilage lesion and bone marrow edema pattern in a 24-month longitudinal study. Skeletal Radiol 2011;40:1315-27.

90 Kubota $M$, Ishijima $M$, Kurosawa $H$, et al. A longitudinal study of the relationship between the status of bone marrow abnormalities and progression of knee osteoarthritis. J Orthop Sci 2010;15:641-6.

91 Jan $\mathrm{MH}$, Chai $\mathrm{HM}$, Wang $\mathrm{CL}$, et al. Effects of repetitive shortwave diathermy for reducing synovitis in patients with knee osteoarthritis: an ultrasonographic study. Phys Ther 2006:86:236-44.

92 Kawaguchi $\mathrm{K}$, Enokida M, Otsuki R, et al. Ultrasonographic evaluation of medial radial displacement of the medial meniscus in knee osteoarthritis. Arthritis Rheum 2012;64:173-80.

93 Bijsterbosch J, Haugen IK, Malines C, et al. Reliability, sensitivity to change and feasibility of three radiographic scoring methods for hand osteoarthritis. Ann Rheum Dis 2011;70:1465-7.

94 Jans $L$, De Coninck T, Wittoek R, et al. 3 T DCE-MRI assessment of synovitis of the interphalangeal joints in patients with erosive osteoarthritis for treatment response monitoring. Skeletal Radiol 2013;42:255-60.

95 Grainger AJ, Farrant JM, O'Connor PJ, et al. MR imaging of erosions in interphalangeal joint osteoarthritis: is all osteoarthritis erosive? Skeletal Radiol 2007:36:737-45

96 Bartlett SJ, Ling SM, Mayo NE, et al. Identifying common trajectories of joint space narrowing over two years in knee osteoarthritis. Arthritis Care Res (Hoboken) 2011;63:1722-8

97 Bruyere $\mathrm{O}$, Genant $\mathrm{H}$, Kothari $\mathrm{M}$, et al. Longitudinal study of magnetic resonance imaging and standard $\mathrm{X}$-rays to assess disease progression in osteoarthritis. Osteoarthritis Cartilage 2007:15:98-103.

98 Teichtahl AJ, Wluka AE, Wang Y, et al. Obesity and adiposity are associated with the rate of patella cartilage volume loss over 2 years in adults without knee osteoarthritis. Ann Rheum Dis 2009:68:909-13.

99 Teichtahl AJ, Wluka AE, Cicuttini FM. Frontal plane knee alignment is associated with a longitudinal reduction in patella cartilage volume in people with knee osteoarthritis. Osteoarthritis Cartilage 2008;16:851-4

100 Cicuttini F, Hankin J, Jones $G$, et al. Comparison of conventional standing knee radiographs and magnetic resonance imaging in assessing progression of tibiofemoral joint osteoarthritis. Osteoarthritis Cartilage 2005:13:722-7.

101 Felson DT, Lynch J, Guermazi A, et al. Comparison of BLOKS and WORMS scoring systems part II. Longitudinal assessment of knee MRIs for osteoarthritis and suggested approach based on their performance: data from the Osteoarthritis Initiative. Osteoarthritis Cartilage 2010;18:1402-7.

102 Crema MD, Hunter DJ, Burstein D, et al. Association of changes in delayed gadolinium-enhanced MRI of cartilage (dGEMRIC) with changes in cartilage thickness in the medial tibiofemoral compartment of the knee: a 2 year follow-up study using 3.0 T MRI. Ann Rheum Dis 2014;73:1935-41.

103 Fukui N, Yamane S, Ishida S, et al. Relationship between radiographic changes and symptoms or physical examination findings in subjects with symptomatic medial knee osteoarthritis: a three-year prospective study. BMC Musculoskelet Disord 2010;11:269.

104 Eckstein F, Boudreau RM, Wang Z, et al. Trajectory of cartilage loss within 4 years of knee replacement-a nested case-control study from the Osteoarthritis Initiative. Osteoarthritis Cartilage 2014;22:1542-9.

105 Kornaat PR, Kloppenburg M, Sharma R, et al. Bone marrow edema-like lesions change in volume in the majority of patients with osteoarthritis; associations with clinical features. Eur Radiol 2007:17:3073-8.

106 Phan CM, Link TM, Blumenkrantz G, et al. MR imaging findings in the follow-up of patients with different stages of knee osteoarthritis and the correlation with clinical symptoms. Eur Radiol 2006;16:608-18.

107 Zhang Y, Nevitt M, Niu J, et al. Fluctuation of knee pain and changes in bone marrow lesions, effusions, and synovitis on magnetic resonance imaging. Arthritis Rheum 2011;63:691-9.

108 Haugen IK, Slatkowsky-Christensen B, Bøyesen P, et al. Cross-sectional and longitudinal associations between radiographic features and measures of pain and physical function in hand osteoarthritis. Osteoarthritis Cartilage 2013:21:1191-8.

109 Bandinelli F, Fedi R, Generini S, et al. Longitudinal ultrasound and clinical follow-up of Baker's cysts injection with steroids in knee osteoarthritis. Clin Rheumatol 2012;31:727-31.
110 Keen HI, Wakefield RJ, Hensor EMA, et al. Response of symptoms and synovitis to intra-muscular methylprednisolone in osteoarthritis of the hand: an ultrasonographic study. Rheumatology (Oxford) 2010;49:1093-100.

111 Klauser AS, Faschingbauer R, Kupferthaler K, et al. Sonographic criteria for therapy follow-up in the course of ultrasound-guided intra-articular injections of hyaluronic acid in hand osteoarthritis. Eur J Radiol 2012:81:1607-11.

112 Brealey SD, DAMASK (Direct Access to Magnetic Resonance Imaging: Assessment for Suspect Knees) Trial Team. Influence of magnetic resonance of the knee on GPs' decisions: a randomised trial. Br J Gen Pract 2007;57:622-9.

113 Ritchie JF, Al-Sarawan M, Worth R, et al. A parallel approach: the impact of schuss radiography of the degenerate knee on clinical management. Knee 2004;11:283-7.

114 Dolin SJ, Williams AC, Ashford N, et al. Factors affecting medical decision-making in patients with osteoarthritis of the hip: allocation of surgical priority. Disabil Rehabil 2003:25:771-7.

115 Bhattacharya $\mathrm{R}$, Kumar $\mathrm{V}$, Safawi E, et al. The knee skyline radiograph: its usefulness in the diagnosis of patello-femoral osteoarthritis. Int Orthop 2007;31:247-52.

116 Chang CB, Seong SC, Kim TK. Evaluations of radiographic joint space-do they adequately predict cartilage conditions in the patellofemoral joint of the patients undergoing total knee arthroplasty for advanced knee osteoarthritis? Osteoarthritis Cartilage 2008;16:1160-6.

117 Dervin GF, Feibel RJ, Rody K, et al. 3-Foot standing AP versus 45 degrees PA radiograph for osteoarthritis of the knee. Clin J Sport Med 2001:11:10-16.

118 Waldstein W, Monsef JB, Buckup J, et al. The value of valgus stress radiographs in the workup for medial unicompartmental arthritis. Clin Orthoped Rel Res 2013;471:3998-4003.

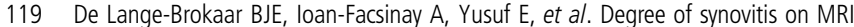
by comprehensive whole knee semi-quantitative scoring method correlates with histologic and macroscopic features of synovial tissue inflammation in knee osteoarthritis. Osteoarthritis Cartilage 2014;22:1606-13.

120 Fernandez-Madrid F, Karvonen RL, Teitge RA, et al. Synovial thickening detected by MR imaging in osteoarthritis of the knee confirmed by biopsy as synovitis. Magn Reson Imaging 1995;13:177-83.

121 Bergman $A G$, Willén $H K$, Lindstrand $A L$, et al. Osteoarthritis of the knee: correlation of subchondral MR signal abnormalities with histopathologic and radiographic features. Skeletal Radiol 1994:23:445-8.

122 Broderick LS, Turner DA, Renfrew DL, et al. Severity of articular cartilage abnormality in patients with osteoarthritis: evaluation with fast spin-echo MR vs arthroscopy. AJR Am J Roentgen 1994;162:99-103.

123 Kalunian KC, Arnold WJ, Klashman DJ, et al. Can physical signs or magnetic resonance imaging substitute for diagnostic arthroscopy in knee osteoarthritis patients with suspected internal derangements?: a pilot study. J Clin Rheumatol 2000:6:123-7.

124 Loeuille D, Sauliere N, Champigneulle J, et al. Comparing non-enhanced and enhanced sequences in the assessment of effusion and synovitis in knee OA: associations with clinical, macroscopic and microscopic features. Osteoarthritis Cartilage 2011:19:1433-9.

125 Saadat $\mathrm{E}$, Jobke B, Chu B, et al. Diagnostic performance of in vivo 3-T MRI for articular cartilage abnormalities in human osteoarthritic knees using histology as standard of reference. Eur Radiol 2008;18:2292-302.

126 Takayama $Y$, Hatakenaka M, Tsushima $H$, et al. T1 $\rho$ is superior to T2 mapping for the evaluation of articular cartilage denaturalization with osteoarthritis: radiological-pathological correlation after total knee arthroplasty. Eur J Radiol 2013;82:e192-8.

127 von Engelhardt LV, Lahner M, Klussmann A, et al. Arthroscopy vs. MRI for a detailed assessment of cartilage disease in osteoarthritis: diagnostic value of MRI in clinical practice. BMC Musculoskelet Disord 2010;11:75.

128 Wong CS, Yan $\mathrm{CH}$, Gong NJ, et al. Imaging biomarker with T1 $\rho$ and T2 mappings in osteoarthritis - in vivo human articular cartilage study. Eur J Radiol 2013:82:647-50.

129 Yoshioka H, Stevens K, Hargreaves BA, et al. Magnetic resonance imaging of articular cartilage of the knee: comparison between fat-suppressed three-dimensional SPGR imaging, fat-suppressed FSE imaging, and fat-suppressed three-dimensional DEFT imaging, and correlation with arthroscopy. J Magn Reson Imaging 2004:20:857-64.

130 Zanetti M, Bruder E, Romero J, et al. Bone marrow edema pattern in osteoarthritic knees: correlation between MR imaging and histologic findings. Radiology 2000;215:835-40

131 Graichen $\mathrm{H}$, von Eisenhart-Rothe $\mathrm{R}$, Vogl T, et al. Quantitative assessment of cartilage status in osteoarthritis by quantitative magnetic resonance imaging: technical validation for use in analysis of cartilage volume and further morphologic parameters. Arthritis Rheum 2004;50:811-16.

132 Moon JS, Lee K, Lee HS, et al. Cartilage lesions in anterior bony impingement of the ankle. Arthroscopy 2010;26:984-9.

133 Tol JL, Verhagen RAW, Krips R, et al. The anterior ankle impingement syndrome: diagnostic value of oblique radiographs. Foot Ankle Int 2004;25:63-8 
134 Haims $\mathrm{AH}$, Moore $\mathrm{AE}$, Schweitzer ME, et al. MRI in the diagnosis of cartilage injury in the wrist. AJR Am J Roentgenol 2004;182:1267-70.

135 Taljanovic MS, Graham AR, Benjamin JB, et al. Bone marrow edema pattern in advanced hip osteoarthritis: quantitative assessment with magnetic resonance imaging and correlation with clinical examination, radiographic findings, and histopathology. Skeletal Radiol 2008;37:423-31.

136 Xu L, Hayashi D, Guermazi A, et al. The diagnostic performance of radiography for detection of osteoarthritis-associated features compared with MRI in hip joints with chronic pain. Skeletal Radio 2013:42:1421-8.

137 Le Graverand MP, Mazzuca S, Lassere M, et al., Radiography Working Group of the OARSI-OMERACT Imaging Workshop. Assessment of the radioanatomic positioning of the osteoarthritic knee in serial radiographs: comparison of three acquisition techniques. Osteoarthritis Cartilage 2006;14(Suppl A):A37-43.

138 Merle-Vincent F, Vignon E, Brandt K, et al. Superiority of the Lyon schuss view over the standing anteroposterior view for detecting joint space narrowing, especially in the lateral tibiofemoral compartment, in early knee osteoarthritis. Ann Rheum Dis 2007;66:747-53.

139 Nelson AE, Renner JB, Shi XA, et al. Cross-sectional comparison of extended anteroposterior and posteroanterior fixed flexion positioning to assess radiographic osteoarthritis at the knee: the Johnston County Osteoarthritis Project. Arthritis Care Res (Hoboken) 2010;62:1342-5.

140 Takahashi T, Yamanaka N, Ikeuchi M, et al. Reproducibility of joint space width and the intermargin distance measurements in patients with medial osteoarthritis of the knee in various degrees of flexion. Skeletal Radiol 2009;38:37-42.

141 Wolfe F, Lane NE, Buckland-Wright C. Radiographic methods in knee osteoarthritis: a further comparison of semiflexed (MTP), schuss-tunnel, and weight-bearing anteroposterior views for joint space narrowing and osteophytes. J Rheumatol 2002:29:2597-601.

142 Buckland-Wright JC, MacFarlane DG, Jasani MK, et al. Quantitative microfocal radiographic assessment of osteoarthritis of the knee from weight bearing tunnel and semiflexed standing views. J Rheumatol 1994;21:1734-41.

143 Buckland-Wright JC, Wolfe F, Ward RJ, et al. Substantial superiority of semiflexed (MTP) views in knee osteoarthritis: a comparative radiographic study, without fluoroscopy, of standing extended, semiflexed (MTP), and schuss views. J Rheumatol 1999;26:2664-74.

144 Buckland-Wright JC, Macfarlane DG, Williams SA, et al. Accuracy and precision of joint space width measurements in standard and macroradiographs of osteoarthritic knees. Ann Rheum Dis 1995;54:872-80.

145 Chaisson CE, Gale DR, Gale E, et al. Detecting radiographic knee osteoarthritis: what combination of views is optimal? Rheumatology (Oxford) 2000:39:1218-21.

146 Cline GA, Meyer JM, Stevens R, et al. Comparison of fixed flexion, fluoroscopic semi-flexed and MTP radiographic methods for obtaining the minimum medial joint space width of the knee in longitudinal osteoarthritis trials. Osteoarthritis Cartilage 2006;14(Suppl A):A32-6.

147 Eriksson K, Sadr-Azodi O, Singh C, et al. Stress radiography for osteoarthritis of the knee: a new technique. Knee Surg Sports Traumatol Arthrosc 2010;18:1356-9.

148 Hing C, Raleigh E, Bailey M, et al. A prospective study of the diagnostic potential of the knee tunnel view radiograph in assessing anterior knee pain. Knee 2007;14:29-33.

149 Lanyon P, O'Reilly S, Jones A, et al. Radiographic assessment of symptomatic knee osteoarthritis in the community: definitions and normal joint space. Ann Rheum Dis 1998;57:595-601.

150 Cicuttini FM, Baker J, Hart DJ, et al. Association of pain with radiological changes in different compartments and views of the knee joint. Osteoarthritis Cartilage 1996;4:143-7.

151 Jones AC, Ledingham J, McAlindon T, et al. Radiographic assessment of patellofemoral osteoarthritis. Ann Rheum Dis 1993;52:655-8.

152 McDonnell SM, Bottomley NJ, Hollinghurst D, et al. Skyline patellofemoral radiographs can only exclude late stage degenerative changes. Knee 2011;18:21-3.

153 Auleley GR, Rousselin B, Ayral X, et al. Osteoarthritis of the hip: agreement between joint space width measurements on standing and supine conventional radiographs. Ann Rheum Dis 1998;57:519-23.

154 Conrozier T, Lequesne MG, Tron AM, et al. The effects of position on the radiographic joint space in osteoarthritis of the hip. Osteoarthritis Cartilage 1997:5:17-22.

155 Pessis E, Chevrot A, Drapé JL, et al. Study of the joint space of the hip on supine and weight-bearing digital radiographs. Clin Radiol 1999:54:528-32.

156 Gudbergsen H, Boesen M, Lohmander LS, et al. Weight loss is effective for symptomatic relief in obese subjects with knee osteoarthritis independently of joint damage severity assessed by high-field MRI and radiography. Osteoarthritis Cartilage 2012;20:495-502.

157 Gudbergsen H, Boesen M, Christensen R, et al. Radiographs and low field MRI $(0.2 T)$ as predictors of efficacy in a weight loss trial in obese women with knee osteoarthritis. BMC Musculoskeletl Disord 2011;12:56.

158 Case JP, Baliunas AJ, Block JA. Lack of efficacy of acetaminophen in treating symptomatic knee osteoarthritis: a randomized, double-blind, placebo-controlled comparison trial with diclofenac sodium. Arch Intern Med 2003;163:169-78.
159 Sawitzke AD, Shi $H$, Finco MF, et al. The effect of glucosamine and/or chondroitin sulfate on the progression of knee osteoarthritis: a report from the glucosamine/chondroitin arthritis intervention trial. Arthritis Rheum 2008:58:3183-91.

160 Mazzuca SA, Brandt KD, Chakr R, et al. Varus malalignment negates the structure-modifying benefits of doxycycline in obese women with knee osteoarthritis. Osteoarthritis Cartilage 2010;18:1008-11.

161 Toh EM, Prasad PS, Teanby D. Correlating the efficacy of knee viscosupplementation with osteoarthritic changes on roentgenological examination. Knee 2002;9:321-30.

162 Chao J, Wu C, Sun B, et al. Inflammatory characteristics on ultrasound predict poorer longterm response to intraarticular corticosteroid injections in knee osteoarthritis. J Rheumatol 2010;37:650-5.

163 Anandacoomarasamy A, Bagga $\mathrm{H}$, Ding C, et al. Predictors of clinical response to intraarticular hylan injections-a prospective study using synovial fluid measures, clinical outcomes, and magnetic resonance imaging. I Rheumatol 2008;35:685-90.

164 Knoop J, Dekker J, van der Leeden M, et al. Is the severity of knee osteoarthritis on magnetic resonance imaging associated with outcome of exercise therapy? Arthritis Care Res (Hoboken) 2014;66:63-8.

165 Han SH, Park DY, Kim TH. Prognostic factors after intra-articular hyaluronic acid injection in ankle osteoarthritis. Yonsei Med J 2014;55:1080-6.

166 Sun SF, Hsu CW, Sun HP, et al. The effect of three weekly intra-articular injections of hyaluronate on pain, function, and balance in patients with unilateral ankle arthritis. J Bone Joint Surg Am 2011;93:1720-6.

167 Mallinson PI, Tun JK, Farnell RD, et al. Osteoarthritis of the thumb carpometacarpal joint: correlation of ultrasound appearances to disability and treatment response. Clin Radiol 2013;68:461-5.

168 Wenham CY, Hensor EM, Grainger AJ, et al. A randomized, double-blind, placebo-controlled trial of low-dose oral prednisolone for treating painful hand osteoarthritis. Rheumatology (Oxford) 2012;51:2286-94.

169 Atchia I, Kane D, Reed MR, et al. Efficacy of a single ultrasound-guided injection for the treatment of hip osteoarthritis. Ann Rheum Dis 2011;70: $110-16$.

170 Rennesson-Rey B, Rat AC, Chary-Valckenaere I, et al. Does joint effusion influence the clinical response to a single Hylan GF-20 injection for hip osteoarthritis? Joint Bone Spine 2008;75:182-8.

171 Rozendaal RM, Uitterlinden EJ, van Osch GJVM, et al. Effect of glucosamine sulphate on joint space narrowing, pain and function in patients with hip osteoarthritis; subgroup analyses of a randomized controlled trial. Osteoarthritis Cartilage 2009:17:427-32.

172 Hoeksma HL, Dekker J, Ronday HK, et al. Manual therapy in osteoarthritis of the hip: outcome in subgroups of patients. Rheumatology (Oxford) 2005;44: 461-4.

173 Deshmukh AJ, Panagopoulos G, Alizadeh A, et al. Intra-articular hip injection: does pain relief correlate with radiographic severity of osteoarthritis? Skeletal Radiol 2011;40:1449-54.

174 van Middelkoop M, Arden N, Atchia I, et al. The OA trial bank: meta-analysis of individual patient data show that patients with severe pain or with inflammatory signs detected by ultrasound especially benefit from intra-articular glucocorticoids for knee or hip OA. Ann Rheumatic Dis 2014:73(Suppl 2):749.3-50.

175 Robinson P, Keenan AM, Conaghan PG. Clinical effectiveness and dose response of image-guided intra-articular corticosteroid injection for hip osteoarthritis. Rheumatology (Oxford) 2007:46:285-91.

176 Pendleton A, Millar A, O'Kane D, et al. Can sonography be used to predict the response to intra-articular corticosteroid injection in primary osteoarthritis of the knee? Scandinavian I Rheumatol 2008;37:395-7.

177 Hirsch G, Kitas G, Klocke R. Intra-articular corticosteroid injection in osteoarthritis of the knee and hip: factors predicting pain relief-a systematic review. Semin Arthritis Rheum 2013:42:451-73.

178 Barrett JP Jr, Rashkoff E, Sirna EC, et al. Correlation of roentgenographic patterns and clinical manifestations of symptomatic idiopathic osteoarthritis of the knee. Clin Orthop Rel Res 1990;253:179-83.

179 Im SH, Lee SC, Park YB, et al. Feasibility of sonography for intra-articular injections in the knee through a medial patellar portal. J Ultrasound Med 2009;28:1465-70.

180 Jang SH, Lee SC, Lee JH, et al. Comparison of ultrasound (US)-guided intra-articular injections by in-plain and out-of-plain on medial portal of the knee. Rheumatol Int 2013:33:1951-9.

181 Sibbitt WLJr, Band PA, Kettwich LG, et al. A randomized controlled trial evaluating the cost-effectiveness of sonographic guidance for intra-articular injection of the osteoarthritic knee. I Clin Rheumatol 2011;17:409-15.

182 Karalezli N, Ogun TC, Kartal S, et al. The pain associated with intraarticular hyaluronic acid injections for trapeziometacarpal osteoarthritis. Clin Rheumatol 2007;26:569-71

183 Maricar N, Parkes MJ, Callaghan MJ, et al. Where and how to inject the knee--a systematic review. Semin Arthritis Rheum 2013;43:195-203. 
184 Cunnington J, Marshall N, Hide G, et al. A randomized, double-blind, controlled study of ultrasound-guided corticosteroid injection into the joint of patients with inflammatory arthritis. Arthritis Rheum 2010;62:1862-9.

185 Curtiss HM, Finnoff JT, Peck E, et al. Accuracy of ultrasound-guided and palpation-guided knee injections by an experienced and less-experienced injector using a superolateral approach: a cadaveric study. PM R 2011;3:507-15.

186 Luz KR, Furtado RN, Nunes CC, et al. Ultrasound-guided intra-articular injections in the wrist in patients with rheumatoid arthritis: a double-blind, randomised controlled study. Ann Rheum Dis 2008;67:1198-200.

187 Sibbitt WL, Peisajovich A, Michael AA, et al. Does sonographic needle guidance affect the clinical outcome of intraarticular injections? J Rheumatol 2009;36:1892-902.
188 Balint PV, Kane D, Hunter J, et al. Ultrasound guided versus conventional joint and soft tissue fluid aspiration in rheumatology practice: a pilot study. J Rheumatol 2002;29:2209-13.

189 Gaffney K, Ledingham J, Perry JD. Intra-articular triamcinolone hexacetonide in knee osteoarthritis: Factors influencing the clinical response. Anna Rheum Dis 1995;54:379-81.

190 Drakonaki EE, Kho JS, Sharp RJ, et al. Efficacy of ultrasound-guided steroid injections for pain management of midfoot joint degenerative disease. Skeletal Radiol 2011;40:1001-6.

191 Bum Park Y, Ah Choi W, Kim YK, et al. Accuracy of blind versus ultrasound-guided suprapatellar bursal injection. J Clin Ultrasound 2012;40:20-5. 